\title{
ANALISIS YURIDIS TERHADAP PUTUSAN PENGADILAN NEGERI TAKALAR NOMOR : 92/PID.B/2015/PN.TKA DALAM PERKARA PEMBUNUHAN BERENCANA DI KABUPATEN TAKALAR
}

\author{
A k b a r \\ Mahasiswa Program Pascasarjana Universitas Muslim Indonesia Makassar \\ email : akbar1234@ymail.com
}

\section{Abstract}

Judge Consideration in Decision No. 92 / Pid.B / 2015 / PN.Tka is not in accordance with the applicable law, because the judge has not been able to properly assess the facts in the trial. In addition, the application of material law by the judges who passed the decision against Defendant I and Defendant II Article 340 of the Criminal Code in Article 55 paragraph (1) of the Criminal Code is not appropriate, because the elements in the article have not been fulfilled in its entirety.

Keywords: Decision; Judge; court;

\section{Abstrak}

Pertimbangan Hakim dalam Putusan No. 92 / Pid.B / 2015 / PN.Tka tidak sesuai dengan hukum yang berlaku, karena hakim belum dapat menilai dengan baik fakta-fakta dalam persidangan. Selain itu, penerapan hukum materiil oleh hakim yang mengeluarkan putusan terhadap Tergugat I dan Tergugat II Pasal 340 KUHP dalam Pasal 55 ayat (1) KUHP tidak tepat, karena unsur-unsur dalam pasal tersebut belum telah terpenuhi secara keseluruhan.

Kata kunci: Keputusan; Hakim; Pengadilan;

\section{A. PENGANTAR}

Indonesia adalah Negara yang berdasarkan atas hukum, sehingga setiap kegiatan masyarakat harus berdasarkan pada peraturan yang berlaku. Hukum tidak lepas dari kehidupan manusia, karena hukum merupakan aturan untuk mengatur tingkah laku manusia.Dalam kehidupan bermasyarakat segala tingkah lakunya diatur oleh hukum sebagai patokan yang dapat menciptakan ketertiban dan kedamaian dalam kehidupan bermasyarakat, walaupun pada kenyataannya masih banyak masyarakat yang melanggar hukum.Karena itu, mutlak diperlukan Penegak Hukum dan penertiban secara konsistensi dan berkesinambungan.

Hukum dalam fungsinya mengatur seluruh aspek kehidupan berbangsa dan bernegara dapat memberikan konstribusinya secara maksimal kepada pelaksanaan pembangunan, jika aparat hukum dan seluruh lapisan masyarakat tunduk dan patuh terhadap norma hukum, tetapi dalam kenyataannya tidak semua unsur dalam lapisan masyarakat tunduk kepada aturan yang ada.

Di dalam KUHP Indonesia diatur mengenaikejahatan yang mengancam 
Pidana Mati, diantaranya Pasal 104 tentang makar, Pasal 340 tentang Pembunuhan Berencana. Pidana mati dalam KUHP merupakan Pidana pokok atau Pidana utama. Perkembangan yang terjadi di Indonesia dalam konsep rancangan KUHP baru, adalah menjadikan pidana mati sebagai pidana Eksepsional, dalam bentuk pidana bersyarat. Artinya ancaman pidana mati tidak lagi dijadikan sebagai sarana pokok penanggulangan kejahatan, namun merupakan pengecualian, ancaman pidana mati tetap tercantum dan diancamkan dalam KUHP, namun dalam penerapannya akan dilakukan dengan secara selektif.

Kodrat sosial membuat manusia tidak biasa lepas dari masyarakat sekitarnya dan bergantung dengan manusia lainnya. Namun, konsepsi homo momini lupus, yang sedianya tidak diharapkan menjadi momok bagi bangunan masyarakat. Manusia mencelakakan manusia, itulah awalan yang tepat menggambarkan prosesi kejahatan yang berkembang dalam kehidupan manusia dewasa ini. Sifat jahat sebetulnya juga merupakan kodrat yang tidak terhindarkan dari manusia, tapi siapa yang bisa menahannya, dialah pemenang. Dalam hal ini, metode menahan sifat jahat manusia dikenalkan dengan agama serta pendidikan moral.

Implementasi penegakan hukum di Indonesia harus memandang hukum sebagai suatu sistem yang pada dasarnya sistem hukum terdiri dari tiga komponen yaitu struktur, substansi dan kultur hukum. Ketiga komponen tersebut memiliki hubungan timbal balik sehingga harus dikaitkan secara bersama-sama demi tercapainya tujuan hukum yang optimal.

Berdasarkan latar belakang diatas, maka yang menjadi pokok permasalahan yang akan dibahasberkenaan dengan pertimbangan hakim dalam menjatuhkan putusan dalam perkara pembunuhan berencana di Kabupaten Takalar dan penerapan hukum pidana hukum pidana terhadap tindak pidana pembunuhan berencana.

\section{B. ANALISIS DAN PEMBAHASAN}

\section{Pertimbangan Hukum Hakim Dalam Menjatuhkan Pidana Terhadap Putusan Pengadilan Negeri Takalar Nomor:92/Pid.B/2015/PNTKa Dalam Perkara Pembunuhan Berencana di Kabupaten Takalar.}

Pertimbangan Hakim dalam menjatuhkan putusan harus mencerminkan rasa keadilan bagi baik bagi korban maupun terdakwa. Untuk menentukan terdakwa terbukti bersalah atau tidak, Hakim harus berpedoman dalam sistem pembuktian sebagaimana diatur dalam Pasal 184 KUHAP bahwa Hakim tidak boleh menjatuhkan pidana kepada seorang kecuali apabila sekurangkurangya dua alat bukti yang sah ia memperoleh keyakinan bahwa suatu tindakl pidana benar-benar terjadi dan bahwa terdakwalah yang bersalah melakukannya.

Berdasarkan ketentuan tersebut, sistem pembuktian yang dianut oleh KUHP adalah sistem pembuktian yang menurut undang-undang secara gabungan antara sistem pembuktian positif dan negatif. Sistem pembuktian tersebut terdiri dari dua komponen yaitu:

a. Pembuktian harus dilakukan menurut cara dan dengan alat-alat bukti yang 
sah menurut undang-undang;

b. Keyakinan Hakim harus didasarkan atas cara dan dengan alat-alat bukti yang sah menurut undang-undang.

Alat bukti yang sah sebagaimana yand diatur dalam Pasal 184 ayat (1) KUHAP terdiri dari :

a. Keterangan saksi;

b. Ketengan ahli;

c. Surat;

d. Petunjuk;

e. Keterangan terdakwa.

Dalam perkara ini, alat bukti yang sah untuk dijadikan sebagai bahan pertimbangan hakim, yakni keterangan saksi, surat dan keterangan terdakwa. Selain itu, juga dihubungkan dengan barang bukti yang sah diajukan dalam persidangan.Kesesuaian antara masing-masing alat bukti serta barang bukti, maka diperoleh fakta hukum yang berdasar bagi hakim untuk memperoleh keyakinan. Berdasarkan ketentuan Pasal 184 ayat (1) KUHAP, maka keseluruhan alat bukti yang diajukan di persidangan berupa keterangan saksi, alat bukti surat dalam hal ini visum et repertum, dan keterangan terdakwa menunjukkan kesesuaian satu sama lain.

Salah satu usaha untuk mencapai kepastian hukumdengan menegakkan hukum secara tegas adalah melalui kekuasaan hakim, dimana hakim merupakan aparat penegak hukum yang melalui putusannya dapat menjadi tolak ukur tercapainya suatu kepastian hukum.

Kekuasaan Kehakiman diatur dalam UUUD NRI Tahun 1945 BAB IX Pasal 24 dan Pasal 25 serta di dalam Undang-Undang Nomor 48 Tahun 2009. Kekuasaan Kehakiman merupakan Kekuasaan yang merdeka untuk menyelenggarakan peradilan guna menegakkan hukum dan keadilan.Kebebasan dalam melaksanakan wewenang yudisial bersifat mutlak, karena tugas Hakim adalah untuk menegakkan hukum dan keadilan berdasarkan Pancasila, sehingga putusannya mencerminkan rasa keadilan bagi seluruh rakyat Indonesia.

Salah satu yang harus menjadi pertimbangan penting oleh majelis hakim yaitu, Kedatangan yang kedua kalinya korban Irwan Dg. Gassing ke kandang sapi milik saksi Patahuddin Dg. Limpo yang pada waktu itu Terdakwa I Muh. Yunus Dg. Sikki menjaga kandang sapi tersebut.Kemudian Korban datang dari arah Galesong menancapkan gas motornya berulang- ulang, sehingga terdakwa merasa terganggu dan akhirnya menghampiri korban dan terjadilah pembunuhan pada malam itu. Hal ini tentu harus menjadi pertimbangan untuk meringankan para terdakwa, sebab yang menjadi pemicu dalam kasus ini adalah korban itu sendiri.

Hakim kurang mempertimbangkan dalam menilai fakta-fakta persidangan dan cenderung subjektif, sehingga putusan yang dijatuhkan oleh para terdakwa melebihi dari tuntutan penuntut umum, yaitu Pasal 338 KUHP jo Pasal 55 ayat (1) ke-1 KUHP. Dalam kasus ini seandainya saja korban Irwan Dg. Gassing tidak mendatangi terdakwa, maka tentu kasus pembunuhan ini tidak akan terjadi. 
Dalam perkara pembunuhan ini, hakim kurang mempertimbangan teori keseimbangan yaitu paradigma masyarakat yang beranggapan bahwa pemicu dalam kasus pembunuhan ini, yaitu korban Irwan Dg. Gassing itu sendiri.Terdakwa I Muh.Yunus Dg. Sikki hanya menjalankan tugas yang diberikan oleh saksi Patahuddin Dg. Limpo untuk menjaga kandang sapi tersebut.Namun karena kedatangan korban yang kedua kalinya dengan provokasi yang sangat tinggi, sehingga Terdakwa I menghampiri korban kemudian terjadilah pembunuhan ini.Hal ini tentu sangatlah penting dipertimbangkan oleh hakim dalam perkara ini.

Pertimbangan selanjutnya yang harus diperhatikan oleh Hakim, adalah pada saat korban lari ke arah kebun milik saksi Muh.Husain Dg. Ma'ru pada saat selesai penikaman yang dilakukan oleh Terdakwa I Muh. Yunus Dg. Sikki, dan Terdakwa II Muh. Yusuf Dg. Nombong, pada saat itu para terdakwa tidak melakukan pengejaran waktu korban melarikan diri ke kebun, karena terdakwa langsung kembali ke kandang sapi, dan membangunkan saksi Sahyono Dg Mone kemudian menceritakan kejadian tersebut. Berdasarkan keterangan para terdakwa di hadapan persidangan hanya ingin memberikan pelajaran terhadap Korban Irwan Dg. Gassing, tetapi terdakwa dalam hal ini diluar dari batas pengendalian terdakwa.

Seandainya terdakwa melakukan pengejaran pada saat korban lari ke arah kebun, maka jelas perbuatan terdakwa berniat untuk melakukan pembunuhan sebab para terdakwa belum melihat korban dalam keadaan mati.Dalam hal ini, hakim dalam melakukan pertimbangkan kurang menilai hal tersebut.Haruslah objektif dan tidak memihak dalam perkara ini, sebab terkadang hakim terpengaruh oleh keadaan.UU Nomor 48 tahun 2009 tentang kekuasaan kehakiman, tugas hakim untuk mengadili perkara berdimensi menegakkan keadilan dan hukum. Hakim dalam melaksanakan tugasnya harus bebas dan tidak boleh terpengaruh atau memihak kepada siapapun.Jaminan kebebasan ini, diatur dalam Pasal 24 UUD NRI Tahun 1945, bahwa hakim merdeka untuk menyelenggarakan peradilan guna menegakkan hukum dan keadilan.

\section{Penerapan Hukum Pidana Dalam Putusan Pengadilan Negeri Takalar Nomor : 92/Pid.B/2015/PN.TKa Terhadap Perkara Pembunuhan Berencana di Kabupaten Takalar}

Hakim dalam memeriksa perkara, mengadili dan memutus suatu perkara, pertama kali harus menggunakan hukum tertulis sebagai dasar putusannya, jika dalam hukum tertulis tidak cukup dan tidak tepat dalam suatu perkara, maka barulah hakim mencari dan menemukan sendiri hukumnya dari sumber-sumber hukum yang lain, seperti yurispudensi, doktrin, traktat, kebiasaan atau hukum tidak tertulis. Dalam perkara ini, hakim memutuskan menjatuhkan Pidana kepada Para Terdakwa dengan Pasal 340 KUHP jo Pasal 55 ayat (1) ke-1 KUHP dengan pidana penjara terhadap Terdakwa I. Muh Yunus Dg Sikki selama 17 (tujuh belas) Tahun dan Terdakwa II. Muh. Yusuf Dg. Nombong selama 15 (lima belas) Tahun. Dalam hal ini, tentu tidak menjadi sulit bagi majelis hakim dalam menjatuhkan 
putusan, karena hakim menggunakan hukum tertulis dalam putusannya. Hakim dalam memberikan putusan tidak hanya berdasarkan pada UndangUndang yang berlaku saja, tetapi juga harus berdasarkan nilai-nilai hukum yang hidup dalam masyarakat.Untuk itu, dalam memberikan putusan hakim harus berdasar penafsiran hukum yang sesuai dengan rasa keadilan yang tumbuh, hidup dan berkembang dalam masyarakat, juga faktor lain yang mempengaruhi seperti faktor budaya, sosial, ekonomi, politik dan lain-lain. Dengan demikian seorang hakim dalam memberikan putusan terhadap kasus yang sama dapat berbeda, karena antara hakim yang satu dengan yang lainnya mempunyai cara pandang serta dasar pertimbangan yang berbeda pula.

Dalam kasus Pembunuhan pada perkara ini, majelis hakim melakukan penerapan Hukum yang melebihi dari tuntutan Jaksa Penuntut Umum sebelumnya (ultra petita).

Dalam Pasal 340 KUHP mengatur mengenai Pembunuhan Berencana yang rumusannya adalah "Barangsiapa dengan sengaja dan dengan direncanakan terlebih dahulu menghilangkan nyawa orang lain, dipidana karena pembunuhan dengan rencana, dengan pidana mati atau pidana seumur hidup atau selama waktu tertentu, paling lama 20 tahun".

Uraian unsur-unsur pasal tersebut terdiri dari:

\section{a. Barangsiapa}

Barangsiapa adalah setiap orang yang merupakan pelaku dari suatu tindak pidana yang dapat dipertanggungjawabkan segala akibat dari perbuatannya.

Terdakwa I Muh.Yunus Dg. Sikki dan Terdakwa II Muh.Yusuf Dg. Nombong dalam persidangan terbukti bahwa para terdakwa mampu menjawab setiap pertanyaan yang diajukan kepada dirinya, sehingga para terdakwa mampu untuk mempertanggung jawabkan dirinya.Dalam hal ini unsur barangsiapa terpenuhi.

\section{b. Dengan Sengaja}

Dalam hal kesengajaan, terdapat dua teori yaitu teori kehendak (willstheorie) dan teori pengetahuan (voorstellings theorie).Menurut teori kehendak, kesengajaan itu adalah kehendak yang diarahkan untuk mewujudkan perbuatan dan unsur-unsur lain yang dirumuskan dalam tindak pidana. Menurut teori pengetahuan, kesengajaan adalah apa yang diketahui atau dapat dibayangkan pembuat sebelum ia mewujudkan perbuatan sebagaimana dirumuskan dalam tindak pidana.

Berdasarkan keterangan Terdakwa I Muh.Yunus Dg. Sikki dan Terdakwa II Muh. Yusuf Dg. Nombong didalam persidangan, bahwa pada kejadian malam itu para Terdakwa hanya ingin memberikan pelajaran terhadap korban Irwan Dg. Gassing atas sikapnya, meskipun saksi Patahuddin Dg. Limpo telah menyampaikan kepada terdakwa, bahwa hiraukan saja perbuatan korban. Pada saat penikaman terjadi Terdakwa I 
memanggil terdakwa II agar diberi bantuan pada malam itu.Dengan demikian unsur dengan sengaja terpenuhi.

c. Direncanakan terlebih dahulu

Di dalam undang-undang tidak dijelaskan secara rinci mengenai maksud dari kata "direncanakan terlebih dahulu". Menurut Soesilo, yang dimaksud dengan perencanaan terlebih dahulu, adalah timbulnya maksud untuk membunuh, pelaksanaannya itu masih ada tempo bagi si pembuat untuk memikirkan secara tenang, misalnya dengan cara bagaimana pembunuhan itu dilakukan. Tempo ini tidak boleh terlalu sempit sebaliknya juga tidak boleh terlalu lama yang penting, adalah apakah dengan tempo itu si pembuat dengan tenang masih dapat berpikir-pikir, yang sebenarnya ia masih ada kesempatan untuk membatalkan niatnya untuk membunuh itu akan tetapi ia tidak pergunakan.

Menurut Adami Chazawi unsur dengan direncanakan terlebih dahulu pada dasarnya mengandung tiga hal, yaitu:

- Memutuskan kehendak dengan suasana tenang;

- Ada tersedia waktu yang cukup sejak timbulnya kehendak sampai dengan pelaksanaan kehendak;

- Pelaksanaan kehendak (perbuatan) dalam suasana tenang.

Berdasarkan fakta yang terungkap dalam persidangan, Terdakwa melakukan pembunuhan tanpa rencana sebelumnya, sebab Korban Irwan Dg. Gassing yang mendahului datang ke lokasi Terdakwa I Muh.Yunus Dg. Sikki dari arah Galesong menuju Takalar, kemudian korban menarik gas motornya berulang-ulang dengan suara knalpot yang keras, lalu korban menghentikan motornya dan berkomunikasi kepada terdakwa. Setelah berbicara tiba-tiba korban menarik badiknya yang terselip di sarung, kemudian memainkan badiknya ke arah terdakwa, tetapi terdakwa berhasil menghindar dan tidak mengenai tubuh terdakwa. Selanjutnya terdakwa melakukan penyerangan kembali kepada korban sambil memanggil terdakwa Muh.Yusuf Dg. Nombong untuk meminta bantuan, dan akhirnya korban terkena samurai berulang-ulang dari Terdakwa I dan Terdakwa II.Korban kemudian melarikan diri ke kebun milik saksi Muh. Husain Dg. Ma'ru, tetapi para terdakwa tidak melakukan pengejaran.

Melihat unsur dari perencanaan tersebut, maka tentu tidak memenuhi unsur pertama dan kedua, sebab terdakwa tidak pernah berpikir sebelumnya untuk melakukan pembunuhan berencana terhadap Korban Irwan Dg. Gassing.Kejadian ini dipicu oleh korban sendiri yang mendatangi terdakwa pada saat terdakwa disuruh jaga kandang sapi.Samurai yang dipakai oleh para terdakwa, adalah kebiasaan setiap malam menjaga kandang sapi memang selalu tersimpan samurai diatas kandang sapi untuk menjaga keadaan yang terkadang tidak kondusif.Kemudian unsur keduapun tidak terpenuhi sebab Terdakwa I Muh.Yunus Dg. Sikki dan Terdakwa II Muh. Yusuf Dg. Nombong sama sekali tidak punya rencana secara sistematis, mulai dari waktu timbulnya kehendak sampai pelaksanaan kehendak, karena para terdakwa belum melihat korban mati pada saat korban lari ke arah kebun. 
d. Menghilangkan nyawa orang lain

Unsur merampas nyawa orang lain mengandung pengertian adanya akibat yang timbul dari suatu perwujudan keinginan untuk menghilangkan nyawa orang lain, dimana akibat tidak perlu segera terjadi akan tetapi dapat timbul kemudian.

Korban Irwan Dg. Gassing baru ditemukan pada pagi harinya sekitar jam 09.00 WITA di sawah milik saksi Husain Dg. Ma'ru. Akibat dari perbuatan Terdakwa I Muh.Yunus Dg. Sikki dan Terdakwa II Muh.Yusuf Dg. Nombong dengan kejadian penikaman pada malam itu.Dalam hal ini unsur menghilangkan nyawa telah terpenuhi.

Dalam prakteknya walaupun terkadang bertitik tolak dari sikap-sikap seorang hakim yang baik, kerangka landasan berpikir/bertindak namun demikian hakim ternyata seorang manusia biasa yang tidak luput dari kelalaian, kekeliruan, kekhilafan (rechterlijk dwaling), rasa rutinitas, kekurangan hati-hatian dan kesalahan.Praktek peradilan didalamnya ada saja aspek-aspek tertentu yang luput dan kerap kurang diperhatikan hakim dalam membuat putusan.

\section{PENUTUP}

Berdasarkan uraian di atas, maka dapat disimpulkan bahwa pertimbangan Hakim dalam menjatuhkan putusan Nomor : 92/Pid.B/2015/ PN.TKa belum sesuai secara keseluruhan dengan aturan hukum yang berlaku. Sedangkan mengenai Penerapan Hukum Materil oleh majelis hakim dalam putusan Nomor:92/Pid.B/2015/PN.TKa bahwa Hakim menjatuhkan putusan terhadap Terdakwa I dan Terdakwa II Pasal 340 KUHP jo Pasal 55 ayat (1) ke-1 KUHP kurang tepat. Sebab unsur-unsur dalam Pasal tersebut belum terpenuhi secara keseluruhan.Dengan demikian Hakim Dalam menjatuhkan putusan kurang mempertimbangkan fakta-fakta yang terungkap dalam persidangan, karena ituhukuman yang dijatuhkan kepada Terdakwa unsur-unsurnya tidak memenuhi pasal tersebut secara keseluruhan.

\section{DAFTAR PUSTAKA}

Achmad Ali, 2009, Menguak Teori Hukum (Legal Theory) dan Teori Peradilan (Judicialprudence), Kencana Pranada Media Grup: Jakarta.

Andi Hamzah, 2008. Hukum Acara Pidana Indonesia (Edisi Kedua) Sinar Gravika, Jakarta.

Ilham Basri, 2003, Hukum Pidana dan Regulasi Implementasi Indonesia, Alqaprint: Bandung.

Kanter dan Sianturi, 2002, Asas-Asas Hukum Pidana Di Indonesia Dan

Penerapannya, Storia Grafika: Jakarta.

Marpaung, Ledeng, 2009, Asas Teori Praktek Hukum Pidana, Jakarta: Sinar 
Grafika.

Soesilo R., 1985. KUHP Serta Komentar-Komentarnya Lengkap dan Penerapannya, Politea, Bogor.

Satjipto Rahadjo, 1983, MasalahPenegakan Hukum, Aumni: Bandung 